\title{
Why not treat human cancer with interleukin-1 blockade?
}

\author{
Charles A. Dinarello
}

Published online: 28 April 2010

(C) The Author(s) 2010. This article is published with open access at Springerlink.com

\begin{abstract}
The clinical successes of targeting angiogenesis provide a basis for trials of interleukin-1 (IL-1) blockade and particularly anti-IL-1 $\beta$ as an add-on therapy in human metastatic disease. In animal studies for over 20 years, IL-1 has been demonstrated to increase adherence of tumor cells to the endothelium in vitro, and administration of IL-1 to mice increases the number of metastatic colonies and tumor growth. Importantly, reducing endogenous IL-1 activity, particularly IL- $1 \beta$, with the naturally occurring IL-1 receptor antagonist (IL-1Ra) reduces both metastasis as well as tumor burden. Inhibition of IL-1 activity prevents in vivo blood vessel formation induced by products released from hypoxic macrophages or vascular endothelial cell growth factor itself. Mice deficient in IL- $1 \beta$ do not form blood vessels in matrigels embedded with vascular endothelial cell growth factor or containing products of macrophages. Recombinant IL-1Ra (anakinra) has been administered to over 1,000 patients with septic shock resulting in a consistent reduction in all-cause 28-day mortality. Approved for treatment of rheumatoid arthritis, anakinra has a remarkable safety record. Anakinra resulted in decreased blood vessels in the pannus of affected joints in patients with rheumatoid arthritis. Neutralizing monoclonal antibodies to IL- $1 \beta$ and a soluble receptor to IL-1 are approved for treating chronic inflammatory diseases. Given the availability of three therapeutic agents for limiting IL-1
\end{abstract}

C. A. Dinarello $(\square)$

Department of Medicine, University of Colorado,

12700 East 19th Ave., B168,

Aurora, CO, 80045 USA

e-mail: cdinare333@aol.com

\section{A. Dinarello}

Department of Medicine, Radboud University,

Nijmegen Medical Center,

Nijmegen, The Netherlands activity, the safety of blocking IL-1, and the clear benefit of blocking IL-1 activity in animal models of metastasis and angiogenesis, clinical trials of IL-1 blockade should be initiated, particularly as an add-on therapy of patients receiving antiangiogenesis-based therapies.

Keywords Cytokines · Inflammation · Angiogenesis · Inflammasome $\cdot$ Necrosis $\cdot$ Endothelium · Innate immune response

\section{Chronic inflammation and IL-1-mediated carcinogenesis}

Models of interleukin (IL)-1 induced carcinogenesis Chronic rather than acute inflammation is important in the pathogenesis of carcinogenesis. Balkwill et al [1] and Mantovani [2] used the expression "smoldering" inflammation to indicate a local inflammatory process that is subclinical. The role of microenvironment IL-1 has been studied using 3-methylcholanthrene-induced carcinogenesis in the skin. [3] In that study, IL-1 $\beta$ emerged as the culprit, whereas IL- $1 \alpha$ exerts less of a proinflammatory effect. In the microenvironment of 3-methylcholanthrene-induced skin carcinogenesis, tumors developed slower and only in some of IL-1 $\beta$-deficient mice compared with wild-type mice. [3] Not unexpectedly, in mice deficient in their own IL-1Ra and hence without opposition to endogenous IL-1, tumor development was the most rapid. Tumor incidence was similar in wild-type as well as in IL- $1 \alpha$-deficient mice. A sparse leukocyte infiltrate was found at the site of carcinogen injection in IL- $1 \beta$-deficient mice, whereas in IL-1Ra-deficient mice, a dense neutrophilic infiltrate was observed. Treatment of IL-1Ra-deficient mice with recombinant IL-1Ra but not with an inhibitor of tumor necrosis 
factor $(\mathrm{TNF} \alpha)$ abrogated the early leukocytic infiltrate. The late leukocyte infiltrate (day 70), which was dominated by macrophages, was also apparent in wild-type and IL- $1 \alpha$-deficient mice, but was nearly absent in IL- $1 \beta$ deficient mice.

Fibrosarcoma cell lines, established from tumors from IL1Ra-deficient mice and presumably deficient in IL-1Ra, were more aggressive and metastatic than tumor cell lines from wild-type mice. [3] These observations support a general concept that in the microenvironment of chronic inflammation, IL- $1 \beta$ rather than IL- $1 \alpha$ affects carcinogenesis and determines the invasive potential of malignant cells.

Chronic infection, $I L-1 \beta$, and carcinogenesis in humans The best example is the chronic infection with Helicobacter pylori and gastric carcinoma. Here, there is a strong association with the presence of IL- $1 \beta$ or the regulation of the IL-1Ra. [4-7] Polymorphisms in the gene for IL-1 $\beta$ and IL-1Ra are associated with an increase risk of gastric cancer, although some studies fail to find these associations in non-Caucasian populations. [8] Using earlystage gastric carcinoma patients, Glas and coworkers [5] reported that the homozygous polymorphism in the IL-1Ra gene was strongly associated with the presence of this early-stage tumor rather than late stage cancer $(p<0.001)$. These investigators also reported that the combined polymorphisms in IL- $1 \beta$ and TNF $\alpha$ gene clusters are a risk for the diffuse type of gastric carcinoma. [5] In a Korean population, the combination of increased mucosal IL- $1 \beta$ levels in $H$. pylori-infected patients with gastric carcinoma and homozygosity for IL-1 $\beta$-31T single nucleotide polymorphism was associated with increased risk of gastric cancer (odds ratio, 3.4; 95\% confidence interval, 1.5-7.7). [9]

Considering the role of IL-1 as a functional cytokine in host defense against infection, once eliminated by antibiotics, infection and its accompanying inflammation are no longer present and the "on" signal for cytokine production becomes a rapid "off." This mechanism limits the production of cytokines, thereby reducing any negative effect of cytokine-mediated inflammation. In addition to chronic infection, the most likely regulator of the inflammatory process is a recurring irritant. Common examples are certain carcinogens in food, smoking, industrial carcinogens, and ultraviolet light. Nearly all proinflammatory cytokines and chemokines are increased by these agents. [1]

\section{Proinflammatory cytokines: two sides of the same coin}

Before discussing a role for IL-1 in metastasis, one must confront the paradox of the same cytokine being both beneficial and harmful. Mantovani uses the expression "ying and yang" for the same concept, [10]—a concept that is fundamental to cytokine biology. Most cytokines function in host defense against infection; the danger of infection is particularly a threat during the neonatal period and early development. In contrast, with the exception of childhood leukemia, carcinogenesis and metastasis are characteristics of the adult and particularly in aging. Therefore, one could view the production of a cytokine such as IL-1 in the young host as beneficial, whereas the same cytokine may contribute to metastasis in an elderly person. For example, the incidence of multiple myeloma increases with age, and the cytokines IL- 1 and IL-6 are growth, survival, and proangiogenic factors for the myeloma cell. Indeed, blocking IL-1 in patients with smoldering or indolent myeloma reduces IL- 6 production and prolongs progressionfree survival. [11] Proinflammatory cytokines possess several properties that can be considered beneficial to the host when challenged with invasion from bacteria and other microorganisms in the immediate environment. An IL-1mediated increase in adhesion molecules on the endothelium certainly facilitates the emigration of neutrophils into the tissues, which are an absolute requirement for killing of bacteria. The same IL-1-mediated increase in endothelial adhesion molecules facilitates the metastatic process. [12]

\section{IL-1 and metastasis}

As reviewed in Lewis et al., [13] IL-1 expression is elevated in human breast, colon, lung, head and neck cancers, and melanomas, and patients with IL-1 producing tumors have generally bad prognoses. Due to the pleiotropic nature of IL-1, there are several likely mechanisms on how IL-1 promotes tumor growth and metastasis. For example, IL-1 induces several prometastatic genes such as matrix metalloproteinases and endothelial adhesion molecules as well as vascular endothelial cell growth factor (VEGF), chemokines, growth factors, and TGF $\beta$.

Two mouse studies from 1990 demonstrated that a single low dose of IL-1 but not IL- 6 administered just before an intravenous injection of tumor cells would increased the numbers of lung metastasis. [14, 15] These and other studies are consistent with the concept that IL-1 stimulates the expression of endothelial adhesion molecules such as intercellular adhesion molecule-1 (ICAM-1) and vascular adhesion molecule-1 (VCAM-1) as well as prostaglandin E2 [16, 17] and enhances adherence of tumor cells. However, in some studies, the adherence of tumor cells was independent of endothelial cell adhesion molecules but rather on RGD.[15] Using intravital videomicroscopy, IL- $1 \alpha$ pretreatment arrested tumor passage in the liver, enhancing metastasis via RGD, E-selectin, ICAM-1, VCAM-1, and $\alpha-\mathrm{V}$ integrin subunit.[18] In human mela- 
noma cells transduced with IL- $1 \alpha$, there was increased adhesion to endothelial cells and in vivo increased retention in the lung.[19] Lung metastasis is commonly studied using intravenous injection of tumor cells, but metastasis has also been studied in the liver. Injection of tumor cells increases hepatic cell gene expression for IL-1 within 4 to $6 \mathrm{~h}$, and this is followed by increased expression of E-selectin by the hepatic sinusoidal endothelial cells.[20] Local metastasis to the liver can be observed when melanoma cells are injected into the spleen, in which case, IL-1 also increases the metastatic spread.[21] However, in the case of human melanoma cells, there is also a role for expression of integrin VLA-4 of the tumor cells in order to adhere to endothelial cells.[22, 23]

Tumor cells expressing the IL- $1 \beta$ precursor must first activate caspase- 1 in order to process the inactive precursor into active cytokine. Activation of caspase-1 requires autocatalysis of procaspase-1 by the nucleotide-binding domain and leucine-rich repeat containing protein 3 (NLRP3) inflammasome. [24] In late-stage human melanoma cells, spontaneous secretion active IL- $1 \beta$ is observed via constitutive activation of the NLRP3 inflammasome. [25] Unlike human blood monocytes, these melanoma cells require no exogenous stimulation. In contrast, NLRP3 functionality in intermediate stage melanoma cells requires activation of the IL-1 receptor by IL- $1 \alpha$ in order to secrete active IL- $1 \beta$. The spontaneous secretion of IL-1 $\beta$ from melanoma cells was reduced by inhibition of caspase-1 or the use of small interfering RNA directed against the inflammasome component ASC. [25] Supernatants from melanoma cell cultures enhanced macrophage chemotaxis and promoted in vitro angiogenesis, both prevented by pretreating melanoma cells with inhibitors of caspases-1 or IL-1 receptor blockade. [25] These findings implicate IL-1-mediated autoinflammation as contributing to the development and progression of human melanoma option for melanoma patients. Whereas highly metastatic human melanoma secrete active IL-1 $\beta$ including proangiogenic properties, [25] transducing tumor cells with mature IL-1 $\beta$ linked to a signal peptide results in a highly invasive local tumor and mtea to the lung following intravenous injection. [26] In spleens of mice injected with IL-1 $\beta$ and transfectants, immunosuppression was observed. In contrast, in tumors expressing membrane IL- $1 \alpha$, reduced tumorigenicity was observed due to antitumor immunity. [26]

Blocking endogenous IL-1 reduces metastasis Although IL-1 will increase tumor cell metastasis, proof of this concept comes from studies in which metastasis is reduced with blockade of endogenous IL-1 or in mice deficient in IL-1. The first study of this quality was reported in 1993 when treatment of mice with IL-1Ra markedly inhibited the augmentation of lung metastasis to the human melanoma cell A375M in mice treated with endotoxin. [27] Similar findings have been reported for melanoma metastasis where a complete inhibition of lipopolysaccharide augmented hepatic metastasis by IL-1Ra was observed. [12] Using IL-1 itself to augment metastasis, the amount of IL-1Ra was 200-fold greater that IL-1. [27] IL-1Ra treatment also reduced the expression of ICAM-1 and VCAM-1. In a model of hepatic metastasis, a single injection of IL-1Ra reduced tumor colonies by $50 \%$ and tumor volume by $70 \%$. [21] The importance of these studies using a single dose of IL-1Ra is the remarkable short half-life of IL-1Ra in the mouse and the relatively prolonged effect of a short time of IL-1RI blockade. Even when a single dose was given after the tumor cell, there was reduced tumor volume by $58 \%$ but with 10 daily doses; hepatic metastasis was reduced $80 \%$. [21] These studies reveal a role for endogenous IL-1 in the metastatic process. However, in a model of melanoma bone metastasis, neutralizing antimouse IL- $1 \alpha$ antibodies did not reduce metastasis [16].

Human melanoma cells producing high levels of constitutive IL- $1 \alpha$ were virally transduced with IL-1Ra and injected into athymic mice. In vitro, proliferation of the IL-1Ra-transduced cells was lower compared with the same cell line transduced with the empty vector. [28] In vivo, the IL-1Ra-expressing melanoma cells exhibited fewer metastases. In a screen of human melanoma tumor samples, copy number greater than 1,000 for IL- $1 \beta$ was present in 14 of 16 biopsies, whereas none expressed IL$1 \alpha$. [29] Similar findings were observed for colon carcinoma and non-small cell lung carcinoma. In contrast, melamoma cell lines express IL- $1 \alpha$ and not IL- $1 \beta$. Tumor supernatant from these cell lines produced a significant increase in endothelial cell monolayer permeability, a hallmark of early angiogenesis, in an IL-1-dependent manner. [29] When injected subcutaneously into athymic mice, administration of IL-1Ra reduced tumor growth of IL-1-expressing tumors but not of tumors without constitutive IL-1 production. [29] When injected intravenously, significantly fewer lung metastases were present 35 days later. Gene expression in tumors taken from mice treated with IL-1Ra revealed lower levels of 100 genes, and steady-state gene expression for IL-8 was reduced 5-fold. VEGF gene expression was markedly reduced in tumors of mice treated with IL-1Ra. [29] Taken together, human and murine melanoma cells appear particularly dependent on IL-1 for invasiveness and proliferation. As reviewed below, there is also a strong case for IL-1 in melanomaassociated angiogenesis.

\section{IL-1-mediated angiogenesis}

No one doubts that angiogenesis and inflammation are linked and pivotal processes in the progression of many 
diseases, particularly malignancies. Once a malignant cell emerges from the milieu of chronic inflammation, proinflammatory cytokines are exploited to provide mechanisms for tumor cell expansion by inducing growth factors from stromal cells such as IL-6 and fibroblast growth factor (FGF). Next, cytokines are used to stimulate angiogenesis. In the case of IL-1, several studies provide evidence that angiogenesis and vascular endothelial growth factor (VEGF) is IL-1 dependent. [26, 29-32] Nylon disks impregnated with either basic FGF or VEGF were implanted into one cornea of rats and then treated with IL-1 (anakinra) or TNF $\alpha$ (soluble receptors) blockade for 7 days. IL-1 blockade dose-dependently reduced corneal angiogenesis, whereas TNF $\sigma$ blockade had no effect. [32] In humans with rheumatoid arthritis, daily anakinra reduces the number blood vessel in the pannus. [33]

In IL-1 $\beta$-deficient mice, local tumor growth or lung metastases of murine melanoma cells were not observed compared with wild-type mice. [30] Angiogenesis into matrigel plugs containing the melanoma cells was absent in the IL- $1 \beta$-deficient mice and also reduced in IL- $1 \alpha$ deficient mice but not as impressively as in IL-1 $\beta$ deficient mice. The incorporation of IL-1Ra into melanoma-containing plugs in wild-type mice inhibited the ingrowth of blood vessel networks. [30] These effects of host-derived IL- $1 \alpha$ and IL-1 $\beta$ were not restricted to the melanoma model, but were also observed in DA/3 mammary and prostate cancer cell models. [30] In addition to the in vivo findings, IL-1 contributed to the production of VEGF and TNF $\alpha$ in cocultures of peritoneal macrophages and tumor cells. [30]

The hypoxic microenvironment of rapidly growing tumors often results in a milieu of proinflammatory and proangiogenic cytokines produced by infiltrating cells. Macrophages under hypoxic conditions promote angiogenesis by production of several angiogenic factors. How much of hypoxia-induced angiogenesis is IL-1 dependent? Using mouse macrophages subjected to hypoxic conditions, supernatants were incorporated into Matrigel plugs and implanted into mice. Neutralization of IL-1 in the supernatants, particularly IL- $1 \beta$, completely abrogated cell infiltration and angiogenesis. [31] When explanted, the matrigel plugs contained $85 \%$ less VEGF. Similarly, supernatants from macrophages of IL-1 $\beta$-deficient mice did not induce inflammatory or angiogenic responses. There were no inflammatory responses in the recipient mice deficient in IL-1 receptors. Myeloid cells infiltrating into Matrigel plugs were of bone marrow origin and represented the major source of IL-1 and other cytokines/chemokines in the plugs. Cells of endothelial lineage were the main source of VEGF and were recruited mainly from neighboring tissues, rather than from the bone marrow. Using the aortic ring sprouting assay, IL-1 does not directly activate endothelial cell migration, proliferation, and organization into blood vessel-like structures, but rather activates infiltrating cells to produce VEGF. Thus, targeting IL- $1 \beta$ has the potential to inhibit angiogenesis in pathological situations and may be of considerable clinical value.

\section{Are endogenous IL-1Ra levels sufficient to suppress the prometastatic effects of IL-1?}

IL-1Ra versus IL-1 $\beta$ in health The naturally occurring IL-1 receptor antagonist (IL-1Ra) present in the circulation of healthy subjects is in considerable excess to IL- $1 \beta$. Because of the large body of evidence that IL-1, and particularly IL$1 \beta$, significantly contributes to the metastatic process, the concept that endogenous levels of IL-1Ra may be sufficient to oppose the activities of IL-1. Using standard enzymelinked immunosorbent assay (ELISA) or specific radioimmunoassay, the levels in healthy subjects are between 200 and $400 \mathrm{pg} / \mathrm{ml}$. Others report healthy subjects with levels $150-180 \mathrm{pg} / \mathrm{ml} / \mathrm{ml}$ (median, $387 \mathrm{pg} / \mathrm{ml}$ ). [34] The manufacturer of the most commonly used ELISA for IL-1Ra reports a mean serum level of $220 \mathrm{pg} / \mathrm{ml}$, and in another study of serum in healthy subjects, the mean level was $313 \mathrm{pg} / \mathrm{ml}$ (range, 270-360 pg/ml). [35] In general, multiplex assays for IL-1Ra show a wider range (62$4,300 \mathrm{pg} / \mathrm{ml}$ ), although the correlation between the ELISA and multiplex assays is significant. [35] In contrast, IL-1 $\beta$ is rarely found in the circulation in health. In fact, using a specific antibody to human IL-1 $\beta$ (canakinumab), the total daily production of IL-1 $\beta$ was calculated to be approximately $6 \mathrm{ng} /$ day. [36] In humans injected with endotoxin, the levels of IL-1 $\beta$ are below detection (less than $2 \mathrm{pg} / \mathrm{ml} /$ $\mathrm{ml})$ before and elevated for a brief time $(2 \mathrm{~h})$ reaching maximal concentrations of 50 to $60 \mathrm{pg} / \mathrm{ml}$. [37] At the same time, the elevations in IL-1Ra are $6,000 \mathrm{pg} / \mathrm{ml} / \mathrm{ml}$ or 100 fold greater. [37] Similar levels were reported in another study in healthy subjects injected with endotoxin intravenously. [38] Understandably, many infectious diseases and autoimmune diseases are associated with elevated levels of IL-1Ra, but IL-1 itself is a potent inducer of IL-1Ra. In humans injected with increasing doses of IL- $1 \alpha$ or IL- $1 \beta$, the rise in endogenous IL-1Ra was dramatic and observed within 1 hour following a 15 -min infusion of either IL- $1 \alpha$ or IL-1 $\beta$. [39] IL-4 given to humans as part of anticancer treatment is also an inducer of IL-1Ra. [40]

Most in vitro studies on IL-1Ra production are from myeloid cells, but it is doubtful if the serum levels of endogenously produced IL-1Ra are of myeloid origin. Rather, serum IL-1Ra likely represents hepatic production as IL-1Ra is an acute phase protein produced by the liver. [41] Like other acute-phase proteins from the liver, IL-6 induces IL-1Ra and the combination of IL- $1 \beta$ plus IL- 6 is 
particularly effective in inducing IL-1Ra from hepatocytes. [41] In several studies, circulating IL-1Ra correlates with circulating IL-6. In mice with a specific deficiency in IL1 Ra from myeloid cells, a severe form of arthritis develops. [42] However, the level of IL-1Ra in the affected joints is high suggesting that nonmyeloid sources of IL-1Ra contribute to the circulating levels.

Circulating IL-1Ra in cancer Elevated serum IL-1Ra, when significantly elevated above those in cohorts of healthy subjects, can be associated with greater disease severity such as larger tumor burden or metastatic spread (see Table 1). In women with estrogen-receptor negative breast cancer, an elevated level of IL-1Ra is associated with a negative prognosis since the presence of estrogen receptors is considered a positive prognostic factor. [43] As shown in Table 1, there is no dearth of reports in various cohorts of patients showing elevated IL-1Ra levels in different cancers. Although most of the reports contain serum levels of IL-1Ra as determined by a specific ELISA or multiplex assays, there are polymorphisms in $I L-1 R N$ that influence the circulating levels of IL-1Ra. For example, within $I L$ $I R N$, there are variable numbers of tandem repeats comprising 86 base pairs. Allele 2 contains two repeats and is associated with increased circulating levels of IL$1 \mathrm{Ra}$. In a study of 885 patients with lung cancer and 1,024 matched controls without cancer, there was a clear decrease risk in carriers of allele 2, particularly in nonsmokers. [44] In carriers of the $\mathrm{T} / \mathrm{T}$ allele single nucleotide polymorphism (SNP) in $I L-1 R N$, there is also an increase level of circulating IL-1Ra [45] and an association with greater survival with colorectal cancer. [46] In contrast, carriers of the $\mathrm{C} / \mathrm{C}$ allele exhibit lower levels of circulating IL-1Ra and have lower survival rates. [46] In the above study of 180 patients, median survival in carriers of $\mathrm{C} / \mathrm{C}$ was 28 months; of C/T, 29.6 months, and of T/T, 35 months. [46]

Elevated levels can also be associated with less disease compared with patients with the same disease. In this context, a lower level of IL-1Ra may reflect reduced inflammation due to a lower tumor burden or fewer metastatic lesions. It will remain a matter of discussion whether a high level of IL-1Ra is functional, that is, inhibits the proinflammatory properties of IL- $1 \beta$ in metastasis. One can argue that since IL- $1 \alpha$ or IL$1 \beta$ stimulates IL-1Ra production, a lower level of IL-1Ra reflects less functional IL-1 due to inhibition of IL-1 signaling. The counterargument is that reduced IL-1 produc-
Table 1 Associations of levels of IL-1Ra in cancer

\footnotetext{
${ }^{a}$ Based on IL-1Ra SNIP 4251961 TT allele

${ }^{\mathrm{b}}$ Based on IL-1Ra SNIP 4251961 CC allele

${ }^{\mathrm{c}}$ Ascites levels were measured

${ }^{\mathrm{d}}$ In patients with allele 2 of $I L-1 R N$
}

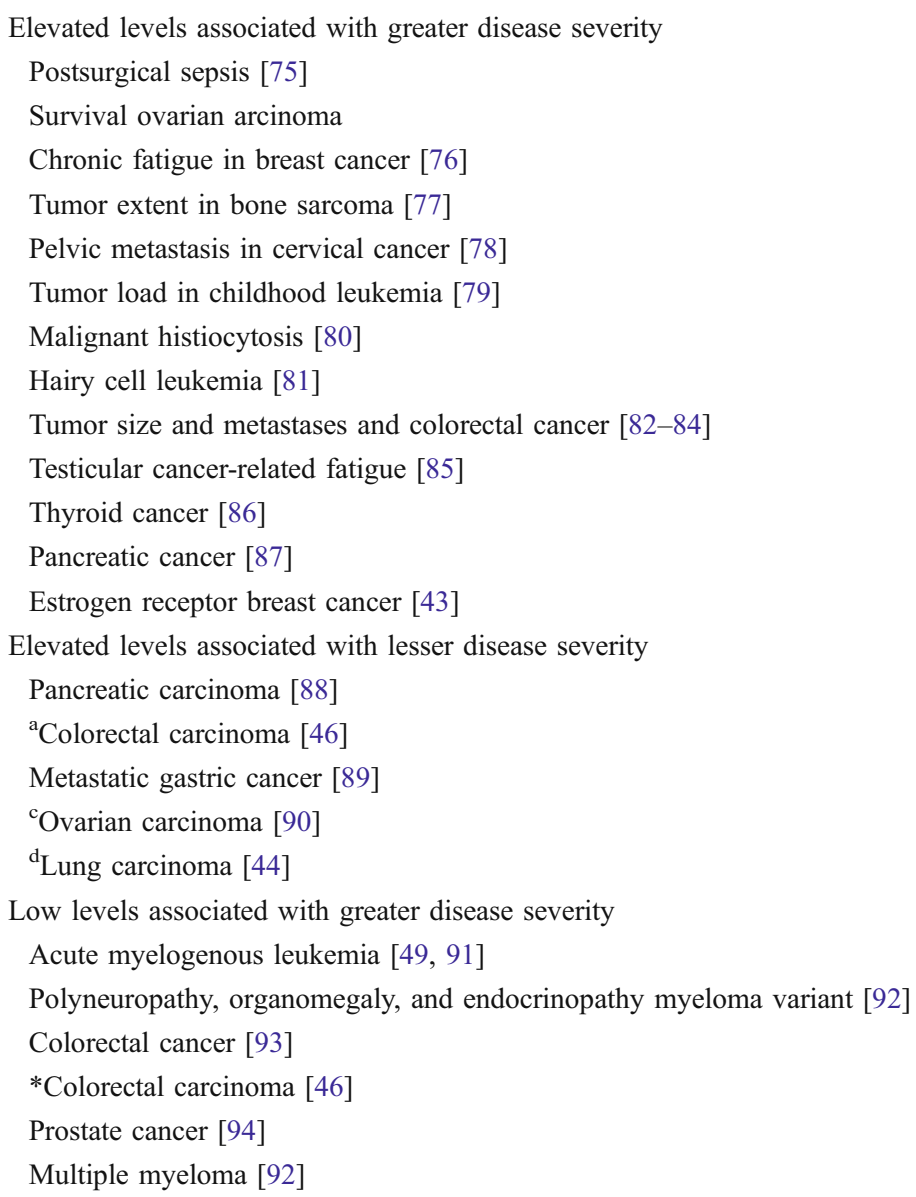


tion for whatever reason results in reduced IL-1Ra levels. The conclusion in either case is that IL-1Ra is at best, a marker for inflammation in cancer.

\section{A hypothesis derived from circulating IL-1Ra levels in cancer}

As shown in Table 1, there are examples of low levels of IL-1Ra associated with active and even severe disease. One can argue that low levels fail to provide sufficient suppression of the activity of endogenous IL-1. Thus, one can hypothesize that endogenous IL-1Ra serves a protective function. Unlike the examples described Table 1 showing high levels of IL-1Ra associated with severe disease, low IL-1Ra levels do not reflect an inflammatory response since there would be more IL-1Ra given the greater amount of cancer. Having lower levels of IL-1Ra associated with greater disease severity suggests that IL-1Ra production is insufficient to counter the prometastatic properties of IL- $1 \beta$. Indeed, this is the case with acute or chronic myelogenous leukemia where low or near-absent IL-1Ra production is associated with greater leukemic burden. [47-49] A similar case can be made for other tumors, although the hypothesis is best appreciated in hematopoietic cancers such as lymphoma, Hodgkin's disease, multiple myeloma, and acute and chronic leukemias. In these diseases, constitutive cell production of IL-1 $\beta$ is high, whereas IL- $1 \mathrm{Ra}$ is low. Therefore, from these cancers, one could conclude that blocking IL-1 $\beta$ would provide for reduced disease.

The concept that there is insufficient endogenous IL-1Ra to counter the proinflammatory properties of IL-1 has both animal as well as human examples. Rabbits passively immunized against their own endogenous IL-1Ra exhibit a worsening of colitis [50] and mice deficient in IL-1Ra developed spontaneous diseases such as a destructive arthritis, [51] an arteritis, [52] and a psoriatic-like skin eruption. Furthermore, mice deficient in endogenous IL$1 \mathrm{Ra}$ develop an aggressive tumors following exposure to carcinogens. [3] These data support the concept that the relative amounts of IL-1 versus IL-1Ra affect the severity of some diseases. A SNP C allele is associated with lower circulating levels of IL-1Ra [45, 53] with a concomitant increase in type 2 diabetes. [53] As stated above, the same polymorphism is associated with reduced survival in patients with colon carcinoma compared with those with the wild-type allele. [46]

The concept of an imbalance between IL-1 $\beta$ and IL-1Ra gained considerable legitimacy with reports of infants born with a genetic basis for nonfunctional IL-1Ra. [54, 55] Soon after birth, the affected infants exhibited impressive systemic and local inflammation. Unless treated with exogenous IL-1Ra, the infants die. Multiple neutrophil- laden pustular skin eruptions, vasculitis, bone abnormalities with large numbers of osteoclasts, osteolytic lesions, and sterile osteomyelitis were observed. The inflammation resembled infection with sepsis-like multiorgan failure, but all cultures were sterile. When treated with daily anakinra, the inflammation abates and the bone lesions reverse. IL-17 was prominently expressed in cells from these patients (see below). These findings are an extreme example that without functional IL-1Ra, the activity of endogenous IL-1 is "unopposed" and IL-1-driven inflammation can run rampant. One can conclude that low levels of IL-1 $\beta$ can induce inflammation, but the presence of natural IL-1Ra is sufficient to limit the inflammation.

IL-1Ra is found in the circulation of healthy subjects in the range of 200 to $300 \mathrm{pg} / \mathrm{ml}$, whereas IL- $1 \beta$ is in the low picogram per milliliter range and is not easily detectable by standard ELISA methods in the same individuals. In healthy humans, daily constitutive production of IL- $1 \beta$ was calculated at $6 \mathrm{ng}$; in patients with cryopyrinassociated periodic syndromes (CAPS), a rare genetic disease due to IL-1 $\beta$ production was calculated at $31 \mathrm{ng} /$ day. [36] These calculations are consistent with reports of increased release of IL-1 $\beta$ from blood monocytes of patients with autoinflammatory diseases. The increase is usually 5 - to 10 -fold more than that from blood monocytes of healthy subjects. [56-58]

\section{IL-1 in multiple myeloma}

Anakinra in a clinical trial Support for this concept comes from studies of IL-1Ra treatment of patients with an evolving progression from a benign condition called monoclonal gammopathy of unspecified significance. Monoclonal gammopathy of unspecified significance and smoldering myeloma present a challenge to medicine as the population ages. [59] Several years of research has focused on the role of IL-1 $\beta$ and IL- 6 in the pathogenesis of multiple myeloma. $[60,61]$ Similar to mature B cells, the myeloma plasma cell produces IL- $1 \beta$. In the microenvironment of the bone marrow, stromal cells respond to low concentrations of IL- $1 \beta$ and release large amounts of IL-6, which in turn promotes the survival and expansion of the myeloma cells. Although IL-6 is an essential growth factor for myeloma cells, antibodies to IL-6 have not been effective in treating the disease, perhaps because the therapy is initiated too late in overt multiple myeloma. Lust et al. [11] reasoned that in the indolent stages of multiple myeloma, blocking IL-1 $\beta$ would provide better reduction of IL-6 activity. Bone marrow cells from patients with smoldering myeloma were cocultured with a myeloma cell line actively secreting IL- $1 \beta$. Although the addition of dexamethasone reduced stromal cell IL- 6 production, the 
amount of IL-6 remained sufficiently high enough to protect the plasma cell against dexamethasone-mediated apoptosis. However, anakinra added to these cocultures significantly reduced IL- 6 by nearly $90 \%$ and the combination of anakinra plus dexamethasone induced myeloma cell death.

Patients with smoldering or indolent myeloma were selected with the clinical objective of slowing or preventing progression to active disease. Based on in vitro data, 47 patients with smoldering/indolent myeloma at high risk for progression to multiple myeloma were treated with daily anakinra for 6 months. During the 6 months, there were decreases in C-reactive protein (CRP) in most but not all patients, which paralleled a decrease in the plasma cell labeling index, a measure of myeloma cell proliferation in unfractionated bone marrow cells. After 6 months of anakinra, a low dose of dexamethasone $(20 \mathrm{mg} /$ week $)$ was added. Of the 47 patients that received anakinra (25 with dexamethasone), progression-free disease was over 3 years and in 8 patients over 4 years [11] compared with historical experience; the findings indicate a significant failure to progress to active disease and a modest fall in CRP predicted responders who continued with stable disease. Patients with a decrease in serum CRP of $15 \%$ or greater after 6 months of anakinra monotherapy resulted in progression-free disease greater than 3 years compared with 6 months in patients with less than a $15 \%$ fall during anakinra therapy $(p<0.002)$. Thus, an effective reduction in IL-1 $\beta$ activity using CRP as the marker for IL- $1 \beta$-induced IL-6 halts progression to active myeloma.

Angiogenesis in multiple myeloma Angiogenesis plays a pathological role in multiple myeloma. As discussed above, there are a growing number of reports on IL- $1 \beta$ as a key cytokine in angiogenesis $[25,26,30-32,62]$. Compared with thalidomide or its analogues, blocking IL-1 $\beta$ is essentially free of toxic side effects. There is an ongoing National Institutes of Health trial of anakinra as an antiangiogenic therapy in patients with cutaneous melanoma. Because blocking IL-1 $\beta$ reduces IL- 6 as well as the proangiogenic chemokine IL- 8 , the use of IL- $1 \beta$ blocking strategies may result in therapy in high-risk patients with smoldering/indolent myeloma or metastatic melanoma. There is also a role for IL- $1 \beta$ in the angiogenic process of macula degeneration, [63] and anakinra treatment in rheumatoid arthritis reduces the vascularization of the pannus. [33]

\section{Blocking IL-1 $\beta$ in metastatic disease in humans}

Does blocking IL-1 $\beta$ interfere with an immunologicallymediated anti-tumor effect? In mouse models, IL- $1 \alpha$ expression on tumor cells can provide an immunologic stimulus such that there is reduce tumor progression. The data are derived from expression of IL- $1 \alpha$ on tumor cells themselves and in such models, IL- $1 \alpha$ remains cell associated, as an intergral membrane protein or intracellularly as a precursor. As reviewed by Apte et al, [64] IL-1 is abundant at tumor sites but membrane-associated IL- $1 \alpha$ expressed on malignant cells stimulates antitumor immunity, whereas secreted IL-1 $\beta$, derived from the microenvironment macrophages or the malignant cells, activates inflammation, which in turn promotes invasiveness. In addition, IL-1 $\beta$ but also induces tumor-mediated suppression. $[26,65]$

Oncogene-transformed fibroblasts, which expressed IL$1 \alpha$, spontaneously regress in their syngeneic host. [66] Regression is significantly influenced by the immune competence of the host and is T-cell-mediated. Frequencies of cytotoxic T-cell precursors were significantly increased after in vivo immunization with IL-1-expressing as compared with IL-1-nonexpressing transformed fibroblasts. IL$1 \alpha$ expression of transformed fibroblasts plays an important role in the induction of a T-cell-mediated antitumor response. As such, a justacrine effect takes place in which membrane IL- $1 \alpha$ attracts immunocompetent cells to the tumor site and assists in an immunologic response that combats tumor growth. This model also serves as the basis for anticancer vaccines, as IL-1 functions as an adjuvant. Understandably, blocking IL-1 activity may seem counterproductive in a proposed use in cancer patients. However, in the same mouse models in which a beneficial effect of IL- $1 \alpha$ can be demonstrated, blocking IL- $1 \beta$ reduces the metastatic spread of tumors.

Regardless of source of inflammation, a persistent local inflammatory process draws inflammatory cells in much the same way a chronic local infection. [67] The persistence of the inflammatory trigger may come from secretion of IL-1 $\beta$ but also from IL- $1 \alpha$ released from necrotic tumor cells. Intracellular IL- $1 \alpha$ is a chromatin-associated cytokine and highly dynamic in the nucleus of living cells. [68] During apoptosis, IL- $1 \alpha$ concentrates in dense nuclear foci. This event markedly reduces its mobile nature of the IL- $1 \alpha$ precursor, and being retained within the chromatin fraction is not released along with the cytoplasmic contents. In contrast, cells undergoing necrosis release their contents and when incorporated in matrigels, recruit cells of the myeloid lineage, whereas lysates of necrotic cells lacking IL- $1 \alpha$ failed to recruit an infiltrate. [68] When normal keratinocytes are subjected to hypoxia, the constitutive IL$1 \alpha$ precursor is released into the supernatant and recruits myeloid cells via an IL-1 $\alpha$-dependent process. [68] Thus, after an ischemic event, which may take place in rapidly growing tumors, the IL- $1 \alpha$ precursor is released by hypoxic cells and incites an inflammatory response by recruiting 
myeloid cells into the area. As such, blocking IL- $1 \alpha$ in such situations may be equally effective in reducing inflammation-induced angiogenesis and metastasis.

\section{Therapeutic options for treating metastatic disease with IL-1 blocking agents}

Current status of use of IL-1 blocking therapeutics in human diseases As listed in Table 2, several IL-1 blocking agents are used successfully in various chronic as well as inflammatory diseases. There are over 30 trials listed in clinicaltrials.gov with IL-1 blocking agents. One trial listed is the use of anakinra in patients with IL-1 producing melanoma, but the results of this trial are not published. Some chronic inflammatory diseases are successfully treated with neutralization by human anti-IL-1 $\beta$ monoclonal antibodies, for example, in type 2 diabetes, either anakinra or a monoclonal antibody to IL- $1 \beta$ improve glycemic control. [53, 69, 70] At this writing, one anti-IL$1 \beta$ antibody (canakinumab) has been approved for treating CAPS, [71] whereas others are presently in clinical trials. Rilonacept is a construct of the two extracellular chains of the IL-1 receptor complex (IL-1RI plus IL-1RAcP) fused to the $\mathrm{Fc}$ segment of IgG and has been approved for use in CAPS. [72]

There are two important considerations for using IL-1 blocking agents in the treatment of metastatic disease and particularly in reducing angiogenesis. First, there are no known organ toxicities. The use of anakinra in patients with rheumatoid arthritis exceeds over 200,000, and many are being treated for over 5 years. Rilonacept and canakinumab have also not been associated with any organ toxicities, gastrointestinal, or hematologic abnormalities. Essentially, there is no maximum tolerated dose for IL-1 blocking agents. Second, although routine bacterial infections and upper airway infections are increased in patients treated with IL-1 blocking agents, unlike other biologicals such as $\mathrm{TNF} \alpha$ blocking treatments, there have been no opportunistic infections. The disadvantage of anakinra is the short plasma half-life (4 hours) necessitating daily injections. The injections are associated with injection site reactions, which subside in most cases after a few weeks. However, the advantage of anakinra is the rapid decrease in the body such that stopping treatment can be necessary when infections develop. Also, anakinra blocks the IL-1 receptor and hence reduces the activity of IL- $1 \alpha$ as well as IL- $1 \beta$. This is not the case with monoclonal antibodies to IL-1 $\beta$. The advantage of anti-IL-1 $\beta$ monoclonal antibodies is the long biological half-life and once-a-month dosing. Rilonacept is intermediate and may neutralize IL- $1 \alpha$ on the cell surface.
Table 2 IL-1 blockade in the treatment of inflammatory diseases ${ }^{\mathrm{a}}$

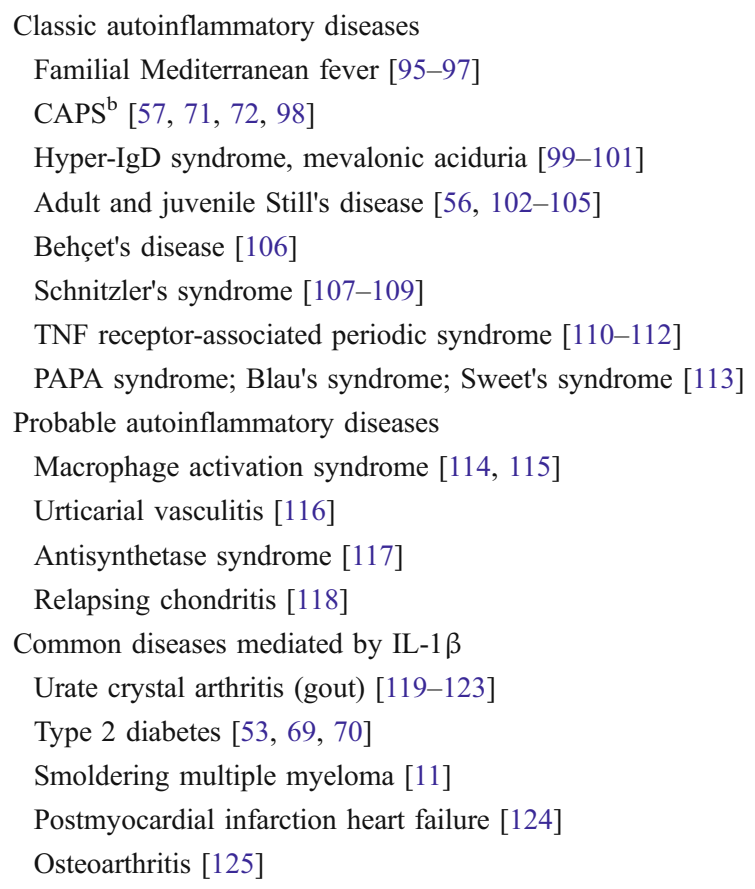

${ }^{\mathrm{b}}$ CAPS is a grouping of familial cold autoinflammatory syndrome, Muckle-Wells syndrome, and neonatal onset multi-inflammatory disease PAPA pyogenic arthritis, pyoderma gangrenosum, and acne

Trial design options Anti-VEGF (bevacizumab) is often added to standard chemotherapy and has resulted in improved survival in colorectal and lung cancer patients and progression-free survival in breast cancer patients. [73] Inhibition of VEGF receptor signaling by tyrosine kinase inhibitors also results in survival benefit. [74] However, bevacizumab used in combination vatalanib, a kinase inhibitor, did not show a benefit. [73] The question is how best to combine IL-1 blocking agents with either antiVEGF or anti-VEGF receptors or kinase inhibitors.

The best trial design option is to add IL-1 blocking therapies to standards of therapy. In the case of monoclonal antibodies to VEGF or antibodies to VEGF receptors, adding an IL-1 blocking agent may increase the antiangiogenic efficacy without increasing the toxic side effects. Alternatively, adding an IL-1 blocking therapeutic may allow the use of a lower dose of anti-VEGF or antibodies to VEGF receptors in order to reduce the toxicities associated with these monoclonal antibodies. The dose-limiting toxicities of bleeding, thrombosis, hypertension, hypothyroidism, proteinuria, edema, and skin lesions associated with antibodies to VEGF or its receptors [74] are unlikely to occur with IL-1 blockade. Small molecule inhibitors of 
VEGFR1, VEGFR2, VEGFR3, basic FGF, PDGFR, and other tyrosine kinase inhibitors have similar unwanted side effects, and their doses may be reduced with anti-IL-1based therapies without sacrificing efficacy.

The possibility of reducing immunosurveillance associated with the use of "biologicals" to treat autoimmune diseases is a common concern. Although there is increasing evidence that there may be an increase in lymphoma associated with anti-TNF $\alpha$ therapies, this association is observed in patients with known increased incidence of hematopoietic cancers before the introduction of biologicals to treat autoimmune diseases. To date, there are no associations of increased malignant disease with IL-1 blocking agents, although by comparison, the numbers of patients receiving anakinra are low compared with those being treated with TNF $\alpha$ blocking therapies. Moreover, patients with autoimmune diseases are treated continuously with TNF $\alpha$ blocking agents, whereas treatment of metastastic disease with IL-1 blockers would likely be in cycles. In mouse models of tumor-associated immunosuppression, blocking IL-1 $\beta$ improves immunoresponsiveness. [26, 65]

\section{Summary}

Anakinra is safe and has been administered to thousands of patients in controlled trials in patients with active infections, chronic inflammatory diseases, and acute inflammatory diseases such as gout and ischemic central nervous cerebrovascular accidents, each with improvement and few if any side effects. High levels $(20 \mu \mathrm{g} / \mathrm{ml})$ can be obtained with infusion rates of 1 and $2 \mathrm{mg} / \mathrm{kg} /$ hour for 72 hours and can likely be administered for longer time periods. Thus, trials for adding anakinra to standards of therapies in patients with metastases seem doable. In particular, adding IL-1 blockade to antiangiogenic based therapies may increase efficacy or reduce the toxic side effects such as hypertensive complications. Anakinra has a remarkable safety record, and in over 250,000 patients, anakinra is not associated with increased susceptibility to Mycobacterium tuberculosis or other opportunistic infections compared with other "biologicals," particularly to anti-tumor necrosis factor (TNF $\alpha$ ). In addition to anakinra, neutralizing monoclonal antibodies to IL-1 $\beta$ and a soluble receptor to IL-1 are approved for treating chronic inflammatory diseases.

There is no dearth of animal studies supporting trials for blocking IL-1 activity in cancer. IL-1 increases adherence of tumor cells to the endothelium in vitro via enhanced expression of E-selectins, RGD, integrins, and adhesion molecules; moreover, administration of IL-1 to mice increases the number of metastatic colonies and tumor growth. Importantly, reducing endogenous IL-1 activity, particularly IL- $1 \beta$, reduces both metastasis and tumor growth. The most compelling argument for IL-1 blockade is the key role for IL-1 in angiogenesis. IL-1 is a potent proangiogenic cytokine, and inhibition of IL-1 activity prevents in vivo blood vessel formation induced by VEGF itself. Mice deficient in IL-1 $\beta$ do not form blood vessels in matrigels embedded with VEGF or containing products released from stimulated macrophages.

\section{Conclusions}

Preclinical evidence provides ample support for reducing IL-1 activity in treating human metastatic disease. The availability of three safe therapeutic agents to block IL-1 activity in humans provides a unique opportunity to increase the efficacy of angiogenesis-targeting agents and or reduce the toxic side effects of these therapies without sacrificing their benefits.

\section{Key unanswered questions}

1. Will blocking IL-1 activity alone reduce metastatic disease in humans?

2. Will the combination of IL-1 blockade with antiangiogenic antibodies or small molecules improve their efficacy?

3. Will the combination of IL-1 blockade with antiangiogenic antibodies or small molecules reduce their side effects?

4. Will blocking IL-1 activity reduce tumor surveillance or antitumor immune mechanisms?

Acknowledgements The author thanks Professors Ron Apte and Elena Voronov of Ben Gurion University of the Negev (Israel) for many years of fruitful collaborations on the role of IL-1 in malignant disease. The author is also grateful to Dr. F. Vidal-Vanaclocha for insights into tumor biology and discussions. Special thanks to Dr. Mayumi Fujita for her fruitful collaborations in human melanoma. These studies were supported by a grant from the National Institutes of Health (AI15614).

Open Access This article is distributed under the terms of the Creative Commons Attribution Noncommercial License which permits any noncommercial use, distribution, and reproduction in any medium, provided the original author(s) and source are credited.

\section{References}

1. Balkwill, F., Charles, K. A., \& Mantovani, A. (2005). Smoldering and polarized inflammation in the initiation and promotion of malignant disease. Cancer Cell, 7, 211-217. 
2. Mantovani, A. (2005). Cancer: inflammation by remote control. Nature, 435, 752-753.

3. Krelin, Y., Voronov, E., Dotan, S., Elkabets, M., Reich, E., Fogel, M., et al. (2007). Interleukin-1beta-driven inflammation promotes the development and invasiveness of chemical carcinogen-induced tumors. Cancer Research, 67, 1062-1071.

4. El-Omar, E. M., Carrington, M., Chow, W. H., McColl, K. E., Bream, J. H., Young, H. A., et al. (2001). The role of interleukin1 polymorphisms in the pathogenesis of gastric cancer. Nature, $412,99$.

5. Glas, J., Torok, H. P., Schneider, A., Brunnler, G., Kopp, R., Albert, E. D., et al. (2004). Allele 2 of the interleukin-1 receptor antagonist gene is associated with early gastric cancer. Journal of Clinical Oncology, 22, 4746-4752.

6. Hamajiama, N., Matsuo, K., Saito, T., Tajima, K., Okujma, K., Yamao, K., et al. (2001). Interleukin-1 polymorphims, lifestyle factors and Helicobacter pylori infection. Japanese Journal of Cancer Research, 92, 383-389.

7. Riedel, S., Kraft, M., Kucharzik, T., Pauels, H. G., Tiemann, M., Steinbuchel, A., et al. (2001). CD4+ Th1-cells predominate in low-grade B-cell lymphoma of gastric mucosa-associated lymphoid tissue (MALT type). Scandinavian Journal of Gastroenterology, 36, 1198-1203.

8. Gatti, L. L., Burbano, R. R., de Assumpcao, P. P., Smith, M. A., \& Payao, S. L. (2004). Interleukin-1beta polymorphisms. Helicobacter pylori infection in individuals from Northern Brazil with gastric adenocarcinoma. Clinical and Experimental Medicine, 4, 93-98.

9. Chang, Y. W., Jang, J. Y., Kim, N. H., Lee, J. W., Lee, H. J., Jung, W. W., et al. (2005). Interleukin-1B (IL-1B) polymorphisms and gastric mucosal levels of IL-1beta cytokine in Korean patients with gastric cancer. International Journal of Cancer, 114, 465-471.

10. Germano, G., Allavena, P., \& Mantovani, A. (2008). Cytokines as a key component of cancer-related inflammation. Cytokine, 43, 374-379.

11. Lust, J. A., Lacy, M. Q., Zeldenrust, S. R., Dispenzieri, A., Gertz, M. A., Witzig, T. E., et al. (2009). Induction of a chronic disease state in patients with smoldering or indolent multiple myeloma by targeting interleukin 1 \{beta\}-induced interleukin 6 production and the myeloma proliferative component. Mayo Clinic Proceedings, 84, 114-122.

12. Vidal-Vanaclocha, F., Alvarez, A., Asumendi, A., Urcelay, B., Tonino, P., \& Dinarello, C. A. (1996). Interleukin 1 (IL-1)dependent melanoma hepatic metastasis in vivo; increased endothelial adherence by IL-1-induced mannose receptors and growth factor production in vitro. Journal of the National Cancer Institute, 88, 198-205.

13. Lewis, A. M., Varghese, S., Xu, H., \& Alexander, H. R. (2006). Interleukin-1 and cancer progression: the emerging role of interleukin-1 receptor antagonist as a novel therapeutic agent in cancer treatment. Journal of Translational Medicine, 4,48 .

14. Giavazzi, R., Garofalo, A., Bani, M. R., Abbate, M., Ghezzi, P., Boraschi, D., et al. (1990). Interleukin 1-induced augmentation of experimental metastases from a human melanoma in nude mice. Cancer Research, 50, 4771-4775.

15. Lauri, D., Bertomeu, M. C., Orr, F. W., Bastida, E., Sauder, D., \& Buchanan, M. R. (1990). Interleukin-1 increases tumor cell adhesion to endothelial cells through an RGD dependent mechanism: in vitro and in vivo studies. Clinical \& Experimental Metastasis, 8, 27-32.

16. Arguello, F., Baggs, R. B., Graves, B. T., Harwell, S. E., Cohen, H. J., \& Frantz, C. N. (1992). Effect of IL-1 on experimental bone/bone-marrow metastases. International Journal of Cancer, $52,802-807$.
17. Mannel, D. N., Orosz, P., Hafner, M., \& Falk, W. (1994). Mechanisms involved in metastasis enhanced by inflammatory mediators. Circulatory Shock, 44, 9-13.

18. Scherbarth, S., \& Orr, F. W. (1997). Intravital videomicroscopic evidence for regulation of metastasis by the hepatic microvasculature: effects of interleukin-1alpha on metastasis and the location of B16F1 melanoma cell arrest. Cancer Research, 57, 4105-4110.

19. Chirivi, R. G., Chiodoni, C., Musiani, P., Garofalo, A., Bernasconi, S., Colombo, M. P., et al. (1996). IL-1alpha genetransfected human melanoma cells increase tumor-cell adhesion to endothelial cells and their retention in the lung of nude mice. International Journal of Cancer, 67, 856-863.

20. Khatib, A. M., Kontogiannea, M., Fallavollita, L., Jamison, B., Meterissian, S., \& Brodt, P. (1999). Rapid induction of cytokine and E-selectin expression in the liver in response to metastatic tumor cells. Cancer Research, 59, 1356-1361.

21. Vidal-Vanaclocha, F., Amezaga, C., Asumendi, A., Kaplanski, G., \& Dinarello, C. A. (1994). Interleukin-1 receptor blockade reduces the number and size of murine B16 melanoma hepatic metastases. Cancer Research, 54, 2667-2672.

22. Martin-Padura, I., Mortarini, R., Lauri, D., Bernasconi, S., Sanchez-Madrid, F., Parmiani, G., et al. (1991). Heterogeneity in human melanoma cell adhesion to cytokine activated endothelial cells correlates with VLA-4 expression. Cancer Research, 51, 2239-2241.

23. Garofalo, A., Chirivi, R. G., Foglieni, C., Pigott, R., Mortarini, R., Martin-Padura, I., et al. (1995). Involvement of the very late antigen 4 integrin on melanoma in interleukin 1-augmented experimental metastases. Cancer Research, 55, 414-419.

24. Dinarello, C. A. (2009). Immunological and inflammatory functions of the interleukin-1 family. Ann Rev Immunol, 27, 519-550.

25. Okamoto, M., Liu, W., Luo, Y., Tanaka, A., Cai, X., Norris, D. A., et al. (2009). Constitutively active inflammasome in human melanoma cells mediating autoinflammation via caspase-1 processing and secretion of interleukin-1beta. The Journal of Biological Chemistry, 285, 6477-6488.

26. Song, X., Voronov, E., Dvorkin, T., Fima, E., Cagnano, E., Benharroch, D., et al. (2003). Differential effects of IL-1alpha and IL-1beta on tumorigenicity patterns and invasiveness. Journal of Immunology, 171, 6448-6456.

27. Chirivi, R. G., Garofalo, A., Padura, I. M., Mantovani, A., \& Giavazzi, R. (1993). Interleukin 1 receptor antagonist inhibits the augmentation of metastasis induced by interleukin 1 or lipopolysaccharide in a human melanoma/nude mouse system. Cancer Research, 53, 5051-5054.

28. Weinreich, D. M., Elaraj, D. M., Puhlmann, M., Hewitt, S. M., Carroll, N. M., Feldman, E. D., et al. (2003). Effect of interleukin 1 receptor antagonist gene transduction on human melanoma xenografts in nude mice. Cancer Research, 63, 5957-5961.

29. Elaraj, D. M., Weinreich, D. M., Varghese, S., Puhlmann, M., Hewitt, S. M., Carroll, N. M., et al. (2006). The role of interleukin 1 in growth and metastasis of human cancer xenografts. Clinical Cancer Research, 12, 1088-1096.

30. Voronov, E., Shouval, D. S., Krelin, Y., Cagnano, E., Benharroch, D., Iwakura, Y., et al. (2003). IL-1 is required for tumor invasiveness and angiogenesis. Proceedings of the National Academy of Sciences of the United States of America, 100, 2645-2650.

31. Carmi, Y., Voronov, E., Dotan, S., Lahat, N., Rahat, M. A., Fogel, M., et al. (2009). The role of macrophage-derived IL-1 in induction and maintenance of angiogenesis. Journal of Immunology, 183, 4705-4714.

32. Coxon, A., Bolon, B., Estrada, J., Kaufman, S., Scully, S., Rattan, A., et al. (2002). Inhibition of interleukin-1 but not tumor necrosis factor suppresses neovascularization in rat models of 
corneal angiogenesis and adjuvant arthritis. Arthritis and Rheumatism, 46, 2604-2612.

33. Cunnane, G., Madigan, A., Murphy, E., FitzGerald, O., \& Bresnihan, B. (2001). The effects of treatment with interleukin-1 receptor antagonist on the inflamed synovial membrane in rheumatoid arthritis. Rheumatology (Oxford), 40, 62-69.

34. Towbin, H., Schmitz, A., van Oostrum, J., Seitz, M., Dewald, B., Zingel, O., et al. (1994). Monoclonal antibody based enzymelinked and chemiluminescent assays for the human interleukin-1 receptor antagonist. Application to measure hIL-1ra levels in monocyte cultures and synovial fluids. Journal of Immunological Methods, 170, 125-135.

35. Dossus, L., Becker, S., Achaintre, D., Kaaks, R., \& Rinaldi, S. (2009). Validity of multiplex-based assays for cytokine measurements in serum and plasma from "non-diseased" subjects: comparison with ELISA. Journal of Immunological Methods, $350,125-132$.

36. Lachmann, H. J., Lowe, P., Felix, S. D., Rordorf, C., Leslie, K., Madhoo, S., et al. (2009). In vivo regulation of interleukin 1beta in patients with cryopyrin-associated periodic syndromes. The Journal of Experimental Medicine, 206, 1029-1036.

37. Granowitz, E. V., Santos, A., Poutsiaka, D. D., Cannon, J. G., Wilmore, D. A., Wolff, S. M., et al. (1991). Circulating interleukin-1 receptor antagonist levels during experimental endotoxemia in humans. Lancet, 338, 1423-1424.

38. Fischer, E., van Zee, K. J., Marano, M. A., Rock, C. S., Kenney, J. S., Poutsiaka, D. D., et al. (1992). Interleukin-1 receptor antagonist circulates in experimental inflammation and in human disease. Blood, 79, 2196-2200.

39. Kopp, W. C., Urba, W. J., Rager, H. C., Alvord, W. G., Oppenheim, J. J., Smith, J. W., 2nd, et al. (1996). Induction of interleukin 1 receptor antagonist after interleukin 1 therapy in patients with cancer. Clinical Cancer Research, 2, 501-506.

40. Atkins, M. B., Vachino, G., Tilg, H. J., Karp, D. D., Robert, N. J., Kappler, K., et al. (1992). Phase I evaluation of thrice-daily intravenous bolus interleukin- 4 in patients with refractory malignancy. Journal of Clinical Oncology, 10, 1802-1809.

41. Gabay, C., Smith, M. F., Eidlen, D., \& Arend, W. P. (1997). Interleukin 1 receptor antagonist (IL-1Ra) is an acute-phase protein. Journal of Clinical Investigation, 99, 2930-2940.

42. Lamacchia, C., Palmer, G., Seemayer, C. A., Talabot-Ayer, D., \& Gabay, C. (2010). Enhanced Th1 and Th17 responses and arthritis severity in mice with a deficiency of myeloid cellspecific interleukin-1 receptor antagonist. Arthritis and Rheumatism, 62, 452-462.

43. Fuksiewicz, M., Kaminska, J., Kotowicz, B., Kowalska, M., Rubach, M., \& Pienkowski, T. (2006). Serum cytokine levels and the expression of estrogen and progesterone receptors in breast cancer patients. Clinical Chemistry and Laboratory Medicine, 44, 1092-1097.

44. Hu, Z., Shao, M., Chen, Y., Zhou, J., Qian, J., Xu, L., et al. (2006). Allele 2 of the interleukin-1 receptor antagonist gene $($ IL1RN*2) is associated with a decreased risk of primary lung cancer. Cancer Letters, 236, 269-275.

45. Rafiq, S., Stevens, K., Hurst, A. J., Murray, A., Henley, W., Weedon, M. N., et al. (2007). Common genetic variation in the gene encoding interleukin-1-receptor antagonist (IL-1RA) is associated with altered circulating IL-1RA levels. Genes and Immunity, 8, 344-351.

46. Graziano, F., Ruzzo, A., Canestrari, E., Loupakis, F., Santini, D., Rulli, E., et al. (2009). Variations in the interleukin-1 receptor antagonist gene impact on survival of patients with advanced colorectal cancer. The Pharmacogenomics Journal, 9, 78-84.

47. Rambaldi, A., Torcia, M., Bettoni, S., Barbui, T., Vannier, E., Dinarello, C. A., et al. (1991). Modulation of cell proliferation and cytokine production in acute myeloblastic leukemia by interleukin-1 receptor antagonist and lack of its expression by leukemic cells. Blood, 78, 3248-3253.

48. Estrov, Z., Kurzrock, R., Estey, E., Wetzler, M., Kantarjian, H., Blake, M., et al. (1992). Inhibition of acute myelogenous leukemia proliferation by IL-1 receptor antagonist and soluble IL-1 receptors. Blood, 79, 1938-1945.

49. Kurzrock, R. (2001). Cytokine deregulation in cancer. Biomedicine \& Pharmacotherapy, 55, 543-547.

50. Ferretti, M., Casini-Raggi, V., Pizarro, T. T., Eisenberg, S. P., Nast, C. C., \& Cominelli, F. (1994). Neutralization of endogenous IL-1 receptor antagonist exacerbates and prolongs inflammation in rabbit immune colitis. Journal of Clinical Investigation, 94, 449-453.

51. Horai, R., Saijo, S., Tanioka, H., Nakae, S., Sudo, K., Okahara, A., et al. (2000). Development of chronic inflammatory arthropathy resembling rheumatoid arthritis in interleukin 1 receptor antagonist-deficient mice. The Journal of Experimental Medicine, 191, 313-320.

52. Nicklin, M. J., Hughes, D. E., Barton, J. L., Ure, J. M., \& Duff, G. W. (2000). Arterial inflammation in mice lacking the interleukin 1 receptor antagonist gene. The Journal of Experimental Medicine, 191, 303-312.

53. Larsen, C. M., Faulenbach, M., Vaag, A., Ehses, J. A., Donath, M. Y., \& Mandrup-Poulsen, T. (2009). Sustained effects of interleukin-1 receptor antagonist treatment in type 2 diabetes. Diabetes Care, 32, 1663-1668.

54. Aksentijevich, I., Masters, S. L., Ferguson, P. J., Dancey, P., Frenkel, J., van Royen-Kerkhoff, A., et al. (2009). An autoinflammatory disease with deficiency of the interleukin-1receptor antagonist. The New England Journal of Medicine, 360, 2426-2437.

55. Reddy, S., Jia, S., Geoffrey, R., Lorier, R., Suchi, M., Broeckel, U., et al. (2009). An autoinflammatory disease due to homozygous deletion of the IL1RN locus. The New England Journal of Medicine, 360, 2438-2444.

56. Pascual, V., Allantaz, F., Arce, E., Punaro, M., \& Banchereau, J. (2005). Role of interleukin-1 (IL-1) in the pathogenesis of systemic onset juvenile idiopathic arthritis and clinical response to IL-1 blockade. The Journal of Experimental Medicine, 201, 1479-1486.

57. Goldbach-Mansky, R., Dailey, N. J., Canna, S. W., Gelabert, A., Jones, J., Rubin, B. I., et al. (2006). Neonatal-onset multisystem inflammatory disease responsive to interleukin-1beta inhibition. The New England Journal of Medicine, 355, 581-592.

58. Gattorno, M., Tassi, S., Carta, S., Delfino, L., Ferlito, F., Pelagatti, M. A., et al. (2007). Pattern of interleukin-1beta secretion in response to lipopolysaccharide and ATP before and after interleukin-1 blockade in patients with CIAS1 mutations. Arthritis and Rheumatism, 56, 3138-3148.

59. Kyle, R. A., Remstein, E. D., Therneau, T. M., Dispenzieri, A., Kurtin, P. J., Hodnefield, J. M., et al. (2007). Clinical course and prognosis of smoldering (asymptomatic) multiple myeloma. The New England Journal of Medicine, 356, 2582-2590.

60. Torcia, M., Lucibello, M., Vannier, E., Fabiani, S., Miliani, A., Guidi, G., et al. (1996). Modulation of osteoclast-activating factor activity of multiple myeloma bone marrow cells by different interleukin-1 inhibitors. Experimental Hematology, 24, 868-874.

61. Lust, J. A., \& Donovan, K. A. (1999). The role of interleukin-1 beta in the pathogenesis of multiple myeloma. Hematology/ Oncology Clinics of North America, 13, 1117-1125.

62. Bar, D., Apte, R. N., Voronov, E., Dinarello, C. A., \& Cohen, S. (2004). A continuous delivery system of IL-1 receptor antagonist reduces angiogenesis and inhibits tumor development. The FASEB Journal, 18, 161-163.

63. Olson, J. L., Courtney, R. J., Rouhani, B., Mandava, N., \& Dinarello, C. A. (2009). Intravitreal anakinra inhibits choroidal 
neovascular membrane growth in a rat model. Ocular Immunology and Inflammation, 17, 195-200.

64. Apte, R. N., Dotan, S., Elkabets, M., White, M. R., Reich, E., Carmi, Y., et al. (2006). The involvement of IL-1 in tumorigenesis, tumor invasiveness, metastasis and tumor-host interactions. Cancer and Metastasis Reviews, 25, 387-408.

65. Song, X., Krelin, Y., Dvorkin, T., Bjorkdahl, O., Segal, S., Dinarello, C. A., et al. (2005). CD11b+/Gr-1+ immature myeloid cells mediate suppression of $\mathrm{T}$ cells in mice bearing tumors of IL-1 $\beta$-secreting Cells. Journal of Immunology, 175, 8200-8208.

66. Zoller, M., Douvdevani, A., Segal, S., \& Apte, R. N. (1992). Interleukin-1 production by transformed fibroblasts. II. Influence on antigen presentation and T-cell-mediated anti-tumor response. International Journal of Cancer, 50, 450-457.

67. Colombo, M. P., \& Mantovani, A. (2005). Targeting myelomonocytic cells to revert inflammation-dependent cancer promotion. Cancer Research, 65, 9113-9116.

68. Cohen, I., Rider, P., Carmi, Y., Braiman, A., Dotan, S., White, M. R., et al. (2010). Differential release of chromatin-bound IL1alpha discriminates between necrotic and apoptotic cell death by the ability to induce sterile inflammation. Proceedings of the National Academy of Sciences of the United States of America, 107, 2574-2579.

69. Larsen, C. M., Faulenbach, M., Vaag, A., Volund, A., Ehses, J. A., Seifert, B., et al. (2007). Interleukin-1-receptor antagonist in type 2 diabetes mellitus. The New England Journal of Medicine, 356, 1517-1526.

70. Donath, M. Y., Weder, C., Brunner, A., Keller, C., Whitemore, J., Der, K., et al. (2009). XOMA 052, a potential disease modifying anti-1L-1beta antibody, shows sustained $\mathrm{HbAlc}$ reductions 3 Months after a single injection with no increases in safety parameters in subjects with Type 2 diabetes. Diabetes, 58, A30.

71. Lachmann, H. J., Kone-Paut, I., Kuemmerle-Deschner, J. B., Leslie, K. S., Hachulla, E., Quartier, P., et al. (2009). Use of canakinumab in the cryopyrin-associated periodic syndrome. New England Journal of Medicine, 360, 2416-2425.

72. Hoffman, H. M., Throne, M. L., Amar, N. J., Sebai, M., Kivitz, A. J., Kavanaugh, A., et al. (2008). Efficacy and safety of rilonacept (interleukin-1 trap) in patients with cryopyrin-associated periodic syndromes: Results from two sequential placebo-controlled studies. Arthritis and Rheumatism, 58, 2443-2452.

73. Jain, R. K., Duda, D. G., Clark, J. W., \& Loeffler, J. S. (2006). Lessons from phase III clinical trials on anti-VEGF therapy for cancer. Nature Clinical Practice. Oncology, 3, 24-40.

74. Wu, H.-C., Huang, C.-T., \& Chang, D.-K. (2008). Anti-angiogenic therapeutic drugs fro treatment of human cancer. $J$ Cancer Molecules, 4, 37-45.

75. Mokart, D., Capo, C., Blache, J. L., Delpero, J. R., Houvenaeghel, G., Martin, C., et al. (2002). Early postoperative compensatory anti-inflammatory response syndrome is associated with septic complications after major surgical trauma in patients with cancer. The British Journal of Surgery, $89,1450-1456$

76. Bower, J. E., Ganz, P. A., Aziz, N., \& Fahey, J. L. (2002). Fatigue and proinflammatory cytokine activity in breast cancer survivors. Psychosomatic Medicine, 64, 604-611.

77. Rutkowski, P., Kaminska, J., Kowalska, M., Ruka, W., \& Steffen, J. (2003). Cytokine and cytokine receptor serum levels in adult bone sarcoma patients: correlations with local tumor extent and prognosis. Journal of Surgical Oncology, 84, 151-159.

78. Fujiwaki, R., Iida, K., Nakayama, K., Kanasaki, H., Hata, K., Katabuchi, H., et al. (2003). Clinical significance of interleukin-1 receptor antagonist in patients with cervical carcinoma. Gynecologic Oncology, 89, 77-83.

79. Schmid, I., Schmitt, M., Streiter, M., Meilbeck, R., Haas, R. J., \& Stachel, D. K. (2005). Effects of soluble TNF receptor II
(sTNF-RII), IL-1 receptor antagonist (IL-1 ra), tumor load and hypermetabolism on malnutrition in children with acute leukemia. European Journal of Medical Research, 10, 457-461.

80. Laurencet, F. M., Chapuis, B., Roux-Lombard, P., Dayer, J. M., \& Beris, P. (1994). Malignant histiocytosis in the leukaemic stage: a new entity (M5c-AML) in the FAB classification? Leukemia, 8, 502-506.

81. Barak, V., Nisman, B., Polliack, A., Vannier, E., \& Dinarello, C. A. (1998). Correlation of serum levels of interleukin-1 family members with disease activity and response to treatment in hairy cell leukemia. European Cytokine Network, 9, 33-39.

82. Ito, H., \& Miki, C. (1999). Profile of circulating levels of interleukin-1 receptor antagonist and interleukin-6 in colorectal cancer patients. Scandinavian Journal of Gastroenterology, 34, $1139-1143$.

83. Tao, M., Li, B., Nayini, J., Andrews, C. B., Huang, R. W., Devemy, E., et al. (2000). SCF, IL-1beta, IL-1ra and GM-CSF in the bone marrow and serum of normal individuals and of AML and CML patients. Cytokine, 12, 699-707.

84. Kaminska, J., Kowalska, M. M., Nowacki, M. P., Chwalinski, M. G., Rysinska, A., \& Fuksiewicz, M. (2000). CRP, TNF-alpha, IL-1ra, IL-6, IL-8 and IL-10 in blood serum of colorectal cancer patients. Pathology Oncology Research, 6, 38-41.

85. Orre, I. J., Murison, R., Dahl, A. A., Ueland, T., Aukrust, P., \& Fossa, S. D. (2009). Levels of circulating interleukin-1 receptor antagonist and C-reactive protein in long-term survivors of testicular cancer with chronic cancer-related fatigue. Brain, Behavior, and Immunity, 23, 868-874.

86. Niedzwiecki, S., Stepien, T., Kuzdak, K., Stepien, H., Krupinski, R., Seehofer, D., et al. (2008). Serum levels of interleukin-1 receptor antagonist (IL-1ra) in thyroid cancer patients. Langenbeck's Archives of Surgery, 393, 275-280.

87. Poch, B., Lotspeich, E., Ramadani, M., Gansauge, S., Beger, H. G., \& Gansauge, F. (2007). Systemic immune dysfunction in pancreatic cancer patients. Langenbeck's Archives of Surgery, 392, 353-358.

88. Ebrahimi, B., Tucker, S. L., Li, D., Abbruzzese, J. L., \& Kurzrock, R. (2004). Cytokines in pancreatic carcinoma: correlation with phenotypic characteristics and prognosis. Cancer, 101, 2727-2736.

89. Graziano, F., Ruzzo, A., Santini, D., Humar, B., Tonini, G., Catalano, V., et al. (2005). Prognostic role of interleukin-1beta gene and interleukin-1 receptor antagonist gene polymorphisms in patients with advanced gastric cancer. Journal of Clinical Oncology, 23, 2339-2345.

90. Mustea, A., Pirvulescu, C., Konsgen, D., Braicu, E. I., Yuan, S., Sun, P., et al. (2008). Decreased IL-1 RA concentration in ascites is associated with a significant improvement in overall survival in ovarian cancer. Cytokine, 42, 77-84.

91. Bruserud, O., Aasen, I., Akselsen, P. E., Bergheim, J., Rasmussen, G., \& Nesthus, I. (1996). Interleukin 1 receptor antagonist (IL1RA) in acute leukaemia: IL1RA is both secreted spontaneously by myelogenous leukaemia blasts and is a part of the acute phase reaction in patients with chemotherapy-induced leucopenia. European Journal of Haematology, 57, 87-95.

92. Gherardi, R. K., Belec, L., Soubrier, M., Malapert, D., Zuber, M., Viard, J. P., et al. (1996). Overproduction of proinflammatory cytokines imbalanced by their antagonists in POEMS syndrome. Blood, 87, 1458-1465.

93. Iwagaki, H., Hizuta, A., \& Tanaka, N. (1997). Interleukin-1 receptor antagonists and other markers in colorectal cancer patients. Scandinavian Journal of Gastroenterology, 32, 577-581.

94. Parekh, D. J., Ankerst, D. P., Baillargeon, J., Higgins, B., Platz, E. A., Troyer, D., et al. (2007). Assessment of 54 biomarkers for biopsy-detectable prostate cancer. Cancer Epidemiology, Biomarkers \& Prevention, 16, 1966-1972. 
95. Masters, S. L., Simon, A., Aksentijevich, I., \& Kastner, D. L. (2009). Horror autoinflammaticus: the molecular pathophysiology of autoinflammatory disease (*). Annual Review of Immunology, 27, 621-668.

96. Mitroulis, I., Papadopoulos, V. P., Konstantinidis, T., \& Ritis, K. (2008). Anakinra suppresses familial Mediterranean fever crises in a colchicine-resistant patient. The Netherlands Journal of Medicine, 66, 489-491.

97. Calligaris, L., Marchetti, F., Tommasini, A., \& Ventura, A. (2008). The efficacy of anakinra in an adolescent with colchicine-resistant familial Mediterranean fever. European Journal of Pediatrics, 167, 695-696.

98. Bodar, E. J., Simon, A., de Visser, M., \& van der Meer, J. W. (2009). Complete remission of severe idiopathic cold urticaria on interleukin-1 receptor antagonist (anakinra). The Netherlands Journal of Medicine, 67, 302-305.

99. Bodar, E. J., van der Hilst, J. C., Drenth, J. P., van der Meer, J. W., \& Simon, A. (2005). Effect of etanercept and anakinra on inflammatory attacks in the hyper-IgD syndrome: introducing a vaccination provocation model. The Netherlands Journal of Medicine, 63, 260-264

100. Rigante, D., Ansuini, V., Bertoni, B., Pugliese, A. L., Avallone, L., Federico, G., et al. (2006). Treatment with anakinra in the hyperimmunoglobulinemia $\mathrm{D}$ /periodic fever syndrome. Rheumatology International, 27, 97-100.

101. Cailliez, M., Garaix, F., Rousset-Rouviere, C., Bruno, D., Kone-Paut, I., Sarles, J., et al. (2006). Anakinra is safe and effective in controlling hyperimmunoglobulinaemia D syndrome-associated febrile crisis. Journal of Inherited Metabolic Disease, 29, 763.

102. Fitzgerald, A. A., Leclercq, S. A., Yan, A., Homik, J. E., \& Dinarello, C. A. (2005). Rapid responses to anakinra in patients with refractory adult-onset Still's disease. Arthritis and Rheumatism, 52, 1794-1803.

103. Lequerre, T., Quartier, P., Rosellini, D., Alaoui, F., De Bandt, M., Mejjad, O., et al. (2008). Interleukin-1 receptor antagonist (anakinra) treatment in patients with systemic-onset juvenile idiopathic arthritis or adult onset Still disease: preliminary experience in France. Annals of the Rheumatic Diseases, 67, 302-308

104. Ohlsson, V., Baildam, E., Foster, H., Jandial, S., Pain, C., Strike, H., et al. (2008). Anakinra treatment for systemic onset juvenile idiopathic arthritis (SOJIA). Rheumatology (Oxford), 47, 555-556.

105. Mirkinson, L. J., Nagle, D., Kadom, N., \& Jones, O. Y. (2006). Anakinra therapy in a child with systemic-onset juvenile rheumatoid arthritis after human herpesvirus 6 encephalitis. Journal of Clinical Rheumatology, 12, 83-86.

106. Botsios, C., Sfriso, P., Furlan, A., Punzi, L., \& Dinarello, C. A. (2008). Resistant Behçet disease responsive to anakinra. Annals of Internal Medicine, 149, 284-286.

107. De Koning HD, Bodar EJ, Simon A, van der Hilst JCH, Netea MG, Van der Meer JW (2005) Beneficial response to anakinra and thalidomide in Schnitzler's syndrome. Ann Rheum Dis, J. C. H

108. Eiling, E., Moller, M., Kreiselmaier, I., Brasch, J., \& Schwarz, T. (2007). Schnitzler syndrome: treatment failure to rituximab but response to anakinra. Journal of the American Academy of Dermatology, 57, 361-364.

109. Adam, Z., Krejci, M., Pour, L., Neubauer, J., Prasek, J., \& Hajek, R. (2008). Schnitzler syndrome-report on a fourteen-year course of the disease and an overview of information on the disease. Vnitrni Lékarství, 54, 1140-1153.

110. Simon, A., Bodar, E. J., van der Hilst, J. C. H., Van der Meer, J. W., Fiselier, T. J. W., Cuppen, M. P. J. M., et al. (2004).
Beneficial response to interleukin-1 receptor antagonist in TRAPS. The American Journal of Medicine, 117, 208-210.

111. Sacre, K., Brihaye, B., Lidove, O., Papo, T., Pocidalo, M. A., Cuisset, L., et al. (2008). Dramatic improvement following interleukin 1beta blockade in tumor necrosis factor receptor-1associated syndrome (TRAPS) resistant to anti-TNF-alpha therapy. The Journal of Rheumatology, 35, 357-358.

112. Gattorno, M., Pelagatti, M. A., Meini, A., Obici, L., Barcellona, R., Federici, S., et al. (2008). Persistent efficacy of anakinra in patients with tumor necrosis factor receptor-associated periodic syndrome. Arthritis and Rheumatism, 58, 1516-1520.

113. Brenner, M., Ruzicka, T., Plewig, G., Thomas, P., \& Herzer, P. (2009). Targeted treatment of pyoderma gangrenosum in PAPA (pyogenic arthritis, pyoderma gangrenosum and acne) syndrome with the recombinant human interleukin-1 receptor antagonist anakinra. The British Journal of Dermatology, 161, 1199-1201.

114. Kelly, A., \& Ramanan, A. V. (2008). A case of macrophage activation syndrome successfully treated with anakinra. Nature Clinical Practice. Rheumatology, 4, 615-620.

115. Chou, R. C., Dinarello, C. A., Ferry, J. A., \& Dal Cin, P. (2010). A 36-year-old woman with recurrent high-grade fevers, hypotension, and hypertriglyceridemia. Arthritis Care and Research, 62, 137-140.

116. Botsios, C., Sfriso, P., Punzi, L., \& Todesco, S. (2007). Noncomplementaemic urticarial vasculitis: Successful treatment with the IL-1 receptor antagonist, anakinra. Scandinavian Journal of Rheumatology, 36, 236-237.

117. Furlan, A., Botsios, C., Ruffatti, A., Todesco, S., \& Punzi, L. (2008). Antisynthetase syndrome with refractory polyarthritis and fever successfully treated with the IL-1 receptor antagonist, anakinra: a case report. Joint, Bone, Spine, 75, 366-367.

118. Chauffier, K., London, J., Beaudouin, C., \& Fautrel, B. (2009). Indications of anakinra. La Presse Médicale, 38, 799-807.

119. So, A., De Smedt, T., Revaz, S., \& Tschopp, J. (2007). A pilot study of IL-1 inhibition by anakinra in acute gout. Arthritis Research \& Therapy, 9, R28.

120. Terkeltaub, R., Sundy, J. S., Schumacher, H. R., Murphy, F., Bookbinder, S., Biedermann, S., et al. (2009). The interleukin 1 inhibitor rilonacept in treatment of chronic gouty arthritis: results of a placebo-controlled, monosequence crossover, nonrandomised, single-blind pilot study. Annals of the Rheumatic Diseases, 68, 1613-1617.

121. Singh, D., \& Huston, K. K. (2009). IL-1 inhibition with anakinra in a patient with refractory gout. Journal of Clinical Rheumatology, 15, 366 .

122. Gratton, S. B., Scalapino, K. J., \& Fye, K. H. (2009). Case of anakinra as a steroid-sparing agent for gout inflammation. Arthritis and Rheumatism, 61, 1268-1270.

123. McGonagle, D., Tan, A. L., Shankaranarayana, S., Madden, J., Emery, P., \& McDermott, M. F. (2007). Management of treatment resistant inflammation of acute on chronic tophaceous gout with anakinra. Annals of the Rheumatic Diseases, 66, 1683-1684.

124. Abbate A, Kontos MC, Grizzard JD, Biondi-Zoccai GL, Van Tassell BW, Robati R, Roach LM, Arena RA, Roberts CF, Varma A, Gelwix C, Salloum FN, Hastillo A, Dinarello CA, Vetrovec GW (2010) Interleukin-1 blockade with anakinra to prevent adverse cardiac remodeling following acute myocardial infarction. Am J Cardiology in press

125. Chevalier, X., Goupille, P., Beaulieu, A. D., Burch, F. X., Bensen, W. G., Conrozier, T., et al. (2009). Intraarticular injection of anakinra in osteoarthritis of the knee: a multicenter, randomized, double-blind, placebo-controlled study. Arthritis and Rheumatism, 61, 344-352. 